\title{
Program Pembelajaran Guru Dalam Menanamkan Nilai-Nilai Kejujuran Di PAUD
}

\author{
Karmawan', Dwi Puji Lestari $^{2}$ \\ ${ }^{1}$ Universitas Islam Syekh Yusuf Tangerang, Indonesia \\ ${ }^{2}$ Sekolah Tinggi Agama Islam Al-Aqidah Al-Hasyimiyyah Jakarta, Indonesia \\ pldwi1022@gmail.com
}

\begin{abstract}
Abstrak
Stres, gelisah, gugup merupakan dampak seseorang tidak jujur. Semakin sering melakukan kebohongan, maka stress, gelisah, dan gugup akan terus didapat. Keadaan kesehatan dan psikologi akan berakibat buruk jika prilaku tidak jujur terus berada dalam diri sesorang. Apalagi prilaku jujur ini tidak ditekankan pada anak usia dini sejak kecil, maka akan memberikan pengaruh buruk untuk perkembangannya. Penelitian bertujuan untuk mengetahui stimulasi yang dilakukan oleh guru untuk menanamkan nilai-nilai kejujuran di PAUD Barisanmu Kids Jatisari Bekasi. Subjek penelitian dalam penelitian ini ada dua guru. Metode penelitian dalam penelitian ini mengunakan metode kualitatif field research. Teknik pengumpulan data mengunakan wawancara, observasi dan dokumentasi. Analisa data mengunakan analisa data miles dan huberman yang terdiri dari reduksi data, penyajian data dan verifikasi atau penarikan kesimpulan. Hasil penelitian menunjukan bahwa program pembelajaran guru dalam menanamkan nilai-nilai melalui kejujuran 1) memberikan program latihan; 2) bekerja sama dengan orang tua di rumah; 3) memberikan pengetahuan tentang nilai-nilai kejujuran; 4) mengunakan metode penanaman nilai dan keteladanan; 5) melakukan perencanaan pembelajaran; 6) memberikan reward (hadiah) dan punishment (hukuman).
\end{abstract}

Kata Kunci: program pembelajaran guru; nilai-nilai kejujuran; teknik guru

\section{Teacher Learning Program in Instilling Honesty Values at PAUD}

\begin{abstract}
Stress, anxiety, nervousness is the impact of someone being dishonest. The more often you lie, the stress, anxiety, and nervousness will continue to be obtained. The state of health and psychology will be bad if dishonest behavior continues to exist in a person. Moreover, this honest behavior is not emphasized in early childhood since childhood, it will have a bad influence on its development. This study aims to determine the stimulation carried out by the teacher to instill the values of honesty in the Barisanmu Kids Jatisari Bekasi PAUD. The research subjects in this study were two teachers. The research method in this study uses a qualitative method field research. Data collection techniques using interviews, observation and documentation. Data analysis uses Miles and Huberman data analysis which consists of data reduction, data presentation and verification or drawing conclusions. The results showed that the teacher's learning program in instilling values through honesty 1) provided an exercise program; 2) cooperate with parents at home; 3) provide knowledge about the values of honesty; 4) using the method of inculcating values and exemplary; 5) carry out learning planning; 6) provide reward (reward) and punishment (punishment).
\end{abstract}

Keywords: teacher learning programs; honesty values; teacher technique 


\section{PENDAHULUAN}

Kasus kejujuran di sekolah bukan merupakan hal yang baru. Sikap tidak jujur dilakukan oleh guru, siswa maupun warga sekolah sekolah. Contoh perilaku tidak jujur yang dilakukan di sekolah diantaranya mencontek tugas atau pekerjaan teman lain, mengorupsi uang sekolah maupun uang kas kelas. Kebanyakan individu ketika memiliki dorongan untuk melanggar biasanya tidak diwujudkan dalam kenyataanya, hal tersebut terjadi karena individu normal biasanya dapat menahan diri dari dorongan-dorongan untuk melakukan perilaku yang bermasalah. Perilaku kecurangan akademik merupakan perilaku yang terdiri atas tiga kategori yaitu (1) memberikan, menggunakan ataupun menerima segala informasi (2) menggunakan materi yang dilarang digunakan dan (3) memanfaatkan kelemahan seseorang, prosedur ataupun suatu proses untuk mendapatkan suatu keuntungan yang dilakukan pada tugas-tugas akademik. Adapun bentuk-bentuk ketidakjujuran akademik menurut McCabe dalam yaitu: (a) bekerja sama dengan orang lain tetapi mengakumengerjakannya sendiri; (b) mengutip dari suatu sumber tertulis dan atau sumber online tetapi tidak mencantumkannya di daftar pustaka; (c) mendapatkan bocoran pertanyaan atau jawaban tes dari orang lain; (d) menerima bantuan saat mengerjakan tugas; (e) memalsukan data penelitian; (f) menggunakan alasan palsu agar dapat menunda mengumpulkan tugas; (g) memalsukan daftar pustaka; (h) menyontek; (i) membantu teman mengerjakan ujian atau tes; (j) menyalin makalah milik orang lain; (k) menyalin sebagian besar tulisan; (1) menyalin hasil tes milik orang lain dan diketahui oleh orang tersebut; (m) membawa contekan saat ujian; (n) hanya setor nama saat tugas kelompok; dan (o) menyalin sebagian besar tulisan di web (Fitria, 2019).

Dalam konteks pembangunan karakter di sekolah, kejujuran menjadi amat penting untuk menjadi karakter anak-anak Indonesia saat ini. Seseorang yang memiliki karakter jujur akan diminati orang lain, baik dalam konteks persahabatan, bisnis, rekan/ mitra kerja, dan sebagainya. Karakter ini merupakan salah satu karakter pokok untuk menjadikan seseorang cinta kebenaran (Dharma Kesuma, 2012). Sekolah merupakan salah satu tempat utama dalam memberikan pendidikan kepada siswa. Sekolah juga merupakan tempat siswa untuk menemukan kesederhanaan dan kejujuran. Belajar tentang etika serta moral, belajar untuk menjadi dirinya, belajar untuk saling mengasihi dan belajar saling membagi. Di sekolah pula siswa dapat memperoleh perlindungan, dan cinta kasih serta membangun karakter mulia dan berbudi luhur. 
Guru memiliki peranan penting dalam pendidikan, terutama dalammenanamkan nilainilai kejujuran. Di anggap sangat penting karena guru seringberhubungan secara langsung dengan siswa dalam proses pembelajaran, saat proses itulah peran guru dalam menanamkan nilai-nilai kejujuran kepada para siswanya. Contoh sederhana peran guru dalam menanamkan kejujuran siswa ialah dengan menyampaikan bahwa ketika ulangan harus dilakukan secara jujurdan tidak menyontek, baik kepada temannya maupun kepada buku catatan. Penyampaian pesan tersebut harus di sampaikan secara sederhana dengan menggunakan bahasa yang dapat dipahami oleh siswa dan harus dilakukan secara rutin dan tak pernah berhenti untuk menyampaikan pesan- pesan moral (Haiatin Chasanatin, 2015).

Guru biasa juga disebut sebagai pendidik, yang artinya orang yang memelihara, merawat dan memberi latihan agar seorang memiliki pengetahuan (Imam Wahyu, 2012). Guru dituntut untuk mempunyai ilmu pengetahuan dan mengikuti perkembangan zaman agar bisa menyesuaikan dengan anak yang meneladaninya disamping itu guru merupakan sosok yang menjadi panutan bagi anak-anak (Annisa Anita Dewi, 2017). Peranan guru berpusat pada mendidik dengan titik berat memberikan arah dan motivasi pencapaian tujuan baik jangka pendek maupun jangka panjang, memberi fasilitas pencapaian tujuan melalui pengalaman belajar yang memadai, membantu perkembangan aspekaspek pribadi seperti tutur kata, sikap, nilai-nilai dan penyesuaian diri (Waseza, 2017).

Dari berbagai pernyataan ahli dapat disimpulkan bahwa peran guru mendidik, memelihara, merawat, memberi latihan sehingga dituntut memiliki ilmu sesuai dengan perkembangan zaman agar menjadi sosok panutan,yang dapat memberikan arah dan motivasi untuk membantu perkembangan aspek-aspek pribadi seperti perkataan dan sikap anak.

Nilai merupakan hal yang terkandung dalam hati nurani manusia yang lebih memberi dasar dan prinsip akhlak yang merupakan standar dari keindahan dan efisiensi atau keutuhan kata hati (potensi) (Fandi Setiawan, 2013). Ya`kub dalam Munir Jujur i al ah suatu sifat dan sikap pribadi seseorang yang setia dan tulus hati dalam melaksanakan suatu yang dipercayakan kepadanya baik berupa harta benda, rahasia, maupun tugas serta kewajiban (Munir dan Sudarsono, 2016). Jujur didalam Al Quran diungkapkan dengan kata shidq. Artinya adalah memberitahukan, menuturkan sesuatu dengan sebenarnya, sesuai dengan fakta (Samsul Munir Amin, 2016). Kejujuran mengacu pada segi karakter moral dan menunjukkan positif,atribut berbudi seperti integritas, kejujuran, dan keterusterangan bersama dengan adanya berbohong, menipu, atau pencurian. 
Pembentukan sikap kejujuran di sekolah ditunjukan dengan beberapa indikator, yaitu (1) tidak meniru jawaban teman (menyontek), (2) mengatakan sesungguhnya sesuatu yang telah terjadi atau sesuatu yang dialaminya dengan apaadanya, (3) mau bercerita tentang kesulitan dan mau menerima pendapat temannya, (4) mau menyatakan tentang ketidaknyamanan suasana belajar di kelas, (5) menjawab pertanyaan guru tentang sesuatu berdasarkan apa yang diketahui (Kementrian Pendidikan Nasional, 2005). Nilai-Nilai kejujuran dapat disimpulkan dasar prinsip yang setia, tulus yang sesuai dengan keadaan sebenarnya. Nilai-nilai kejujuran di sekolah dapat memiliki indicator diantaranya : 1) tidak menyontek; 2) berkata sesungguhnya sesuai fakta; 3) mau bercerita dan menerima masukan; 4) mau mengungkapkan ketidak nyamanan di kelas; 5) mau menjawab pertanyaan guru berdasarkan yang diketahui.

Penelitian terdahulu dengan tema kejujuran telah dilakukan oleh pendidik diantaranya guru sebagai sentral dalam pendidikan di sekolah, memiliki peran yang penting dalam menanamkan nilai kejujuran pada anak. Beberapa hal yang dapat diterapkan oleh guru dalam penanaman nilai kejujuran diantaranya; melakukan pengajaran secara terus-menerus dan terintegrasi antar setiap komponen sekolah, menjadikan dirinya sebagai suri teladan bagi anak didiknya, membiasakan peserta didik untuk berperilaku jujur, melakukan refleksi diri, dan memberikan punishment kepada anak yang berperilaku tidak jujur (Muhammad Amin, 2017) (Dan, 2017), Empat kompetensi yang harus dimiliki guru untuk menanamkan nilai kejujuran yaitu kompetensi akademik, pedagogiek, professional dan sosial. Adanya empat kompetensi guru memiliki peran guru sebanyak tigahal diantaranya pertama, dapat menjadi teladan untuk siswa dalam berperilaku, bertutur kata dan beragama. Kedua, guru seyogyanya mengerti dan menghargai keunikan siswa baik kelebihan maupun kekurangannya, pendapatnya, tidak mencemoohnya, memberikan reward dan pujian yang memadai atas prestasi yang dicapai siswanya. Ketiga guru membimbing siswanya dengan cara menciptakan suasana kelas yang rileks dan mampu menstimulasi perkembangan siswa, menginformasikan cara belajar efektif, melakukan sosialisasi peraturan sekolah agar dapat dipahami oleh siswa manfaat dantujuannya, menciptakan budaya belajar dan karakter yang baik (Rochmawati, 2018). Namun penanaman nilai-nilai kejujuran. PAUD Barisanmu menarik untuk dikaji karena di sekolah ini nilai-nilai kejujuran diprogramkan melalui pembelajaran yang terimplentasi dalam kegiatan oleh guru maka dari itu artikel ini akan menjadi kekayaan ilmu untuk para guru PAUD dalam menanamkan nilai-nilai kejujuran sehingga dapat digunakan sebagai acuan untuk mengajar. 


\section{METODE PENELITIAN}

Jenis penelitian yang digunakan dalam peneitian ini adalah kualitatif deskriptif. Penelitian ini akan mengambarkan tentang peran guru dalam menanamkan nilai kejujuran di PAUD Barisanmu Kids Jatisari Bekasi pada tahun ajaran 2020/2021 selama bulan FebruariMaret. Sumber data dalam penelitian ini adalah dua guru PAUD yang ada di sekolah.. Disamping itu ada sumber sekunder berupa dokumen-dokumen, foto kegiatan yang berkaitan dengan tema penelitian. Teknik pengumpulan data ada tiga yaitu wawanacara, dokumentasi dan observasi. Wawancara dilakukan guru untuk mengetahui metode yang digunakan untuk menanamkan nilai-nilai kejujuran, dokumentasi digunakan untuk mengetahui proses penanaman nilai-nilai kejujuran dan observasi digunakan untuk menanamkan nilai-nilai kejujuran. Teknik analisa data mengunakan analisis dan model Miles and Huberman dengan tiga langkah-langkah yaitu Reduksi data yaitu data yang didapatkan dari tiga Teknik pengumpulan data dicatat dan dikumpulkan. Data display yaitu menyajikan data dari hasil pengumpulan data. Kesimpulan yaitu mengambil kesimpulan dari data yang sudah dikumpulkan.

\section{HASIL DAN PEMBAHASAN}

\section{Hasil}

Paud Barisanmu Kids terletak di Jl. Raya Payangan Gang Al-Hidayah Rt.07 RW.06 Jatiasari Jatiasih, Bekasi. Sekolah ini memiliki tiga guru yang bertugas untuk mengajar. Adapun yang dilakukan oleh program pembelajaran guru dalam menanamkan nilai-nilai kejujuran diantaranya adalah sebagai berikut :

\begin{tabular}{lll}
\hline No & Nama Program Guru & Analisis \\
\hline 1 & Memberikan program latihan & Dalam menanamkan sikap jujur, di Paud \\
& Barisanmu Kids ada program khusus. Program \\
& khususnya yaitu, pihak sekolah mewajibkan \\
& program sedekah dan sholat dhuha pada hari \\
& jum'at bagi semua murid. Hal ini sebagaimana \\
& yang diungkapkan oleh guru: \\
& "Program khusus pihak sekolah mewajibkan \\
& program sedekah dan sholat dhuha pada hari \\
& jum'at bagi semua murid dan orang tua \\
& memberikan uang kepada anak, untuk melatih \\
& anak jujur menyerahkan uang sedekahnya \\
& bukan untuk jajan." (Catatan Wawancara, 20 \\
& Maret 2021). \\
\hline
\end{tabular}


Bekerja sama dengan orang tua di rumah

Guru pengetahuan kejujuran

\section{Program latihan ini digunakan untuk menanamkan nilai-nilai kejujuran pada anak- anak.}

Dalam proses pembelajaran untuk anak usia dini dalam kegiatan sekolah peran guru dalam menanamkan sikap jujur anak usia dini di PAUD Barisanmu Kids tidak lepas dari keterlibatan peran orang tua juga. Hal ini sesuai dengan pernyataan ibu Fuziani:

"Kejujuran sangat penting biasanya terbentuk dari pola asuh orang tua sebagai teladan pertama di rumah, karena orang tua sangat berpengaruh sekali dalam ikut menerapkan kejujuran anak terutama ketika di rumahnya"(Catatan Wawancara, 20 Maret 2021).

$3 \begin{aligned} & \text { Guru } \\ & \text { pengetahuan } \\ & \text { kejujuran }\end{aligned}$

Guru memberikan pengetahuan nilai-nilai kejujuran kepada anak. Sebagaimana yang diungkapkan oleh guru sebagai berikut :

"Memberikan pengetahuan dan keyakinan kepada anak bahwa Allah itu Maha Melihat, suapaya dilatih bahwa dia lihat setiap saat oleh Allah. Jujur itu nikmat dan memberikan pujian kepada anak ketika dia jujur supaya termotivasi bahwa semua orang suka dengan kejujuran.". (Catatan Wawancara, 20 Maret 2021)

Metode yang digunakan guru dalam memberikan pengetahuan sebagaimana yang disampaikan oleh guru :

"Guru memberikan pengetahuan nilai-nilai kejujuran melalui cerita atau mendongeng yang didalamnya terdapat tokoh-tokoh kejujuran. Dari cerita tersebut anak dapat memiliki pengetehuan tentang nilai-nilai kejujuran. Guru juga menyampaikan dampak dari berbohong akan dijauhi oleh teman. Diantara yang diberikan nasehat adalah tidak mencuri, tidak berbohong, Di samping itu juga melalui tepuk kejujuran, (Catatan Wawancara, 21 Maret 2021)

3 Guru mengunakan metode keteladanan

Guru memiliki peran utama dalam menanamkan nilai-nilai kejujuran pada anak di PAUD Kids Barisanmu Bekasi. Perilaku seorang guru di kelas menjadi kunci dalam membantu semua siswanya mencapai potensi tanpa 
4 Guru melakukan perencanaan pembelajaran

Memberikan reward (hadiah)

memandang jenis kelamin, etnis, usia, agama, bahasa atau keistimewaan. (Tarman \& Tarman, 2011). Metode yang digunakan dalam proses pembelajaran di Paud Barisanmu Kids Jatisari juga mengunakan pendekatan penanaman nilai yang disebutkan dengan keteladanan guru, seperti guru mau mengakui kesalahan dan meminta maaf ketika memang guru itu salah, keteladanan lainnya yaitu guru menepati janji ketika memang sudah berjanji kepada peserta didik (Catatan Observasi, 21 Maret 2021)

Sebelum melakukan pembelajaran guru melakukan pembelajaran guru menyusun rencana pembelajaran yang didalamnya mencakup pengembangan nilai kejujuran, menyiapkan media yang dapat menunjang untuk mendukung penyampaian nilai-nilai kejujuran (Observasi, 20 Maret 2021)

Guru dalam merencanakan pembelajaran menaruh karakter kejujuran dalam Rencana Pelaksanaan Pembelajarannya Harian (RPPH) dan punishment (hukuman)

Anak diminta melakukan tugas oleh guru kemudian anak melakukan sesuai dengan interupsi guru. Setelah itu guru memberikan pujian. Contohnya ada seorang anak yang kehilangan buku. Ibu guru meminta tolong kepada anak-anak ketika menemukan buku tersebut untuk segera memberi tahu guru. Benar saja tidak lama kemudian seorang anak perempuan menemukan uang tersebut dan memberikan kepada bu guru. Setelah itu guru memberikan pujian bahwa anak tersebut hebat, baik, dan jujur karna mau mengembalikan buku tersebut dan meminta anak-anak lain untuk memberi tepuk tangan kepada anak tersebut (Hasil Observasi, 22 Maret 2021). Setelah anak diberikan pujian oleh guru anak menjadi sangat semangat dalam melakukan nilai-nilai kejujuran di kelas. Contoh pemberian hukuman, ketika anak-anak akan pulang, maka guru memberi perintah untuk antri, dan berdasarkan hasil observasi penulis melihat ada seorang anak yang tidak mau antri, akhirnya guru meminta anak tersebut untuk baris di barisan paling belakang sebagai hukumannya dan benar saja pada hari berikutnya anak tersebut mau untuk mengantri. Penulis merasa metode tersebut efektif jika memperhatikan teknik dan pendekatan yang tepat 
Dari hasil penelitian yang dilakukan dapat diketahui bahwa strategi guru yang dilakukan di PAUD Barisanmu melalui enam program diantaranya memberikan program pelatihan, bekerjasama dengan orang tua di rumah, guru memberikan pengetahuan nilai-nilai kejujuran, mengunakan metode keteladanan, guru melakukan perencanaan, Memberikan reward (hadiah) dan punishment (hukuman). Keenam program tersebut telah terprogram di sekolah.

\section{Pembahasan}

Kejujuran adalah dasar dari komunikasi yang efektif dan hubungan yang sehat. Ini membuktikan bahwa kejujuran sangat penting, supaya hubungan anak dan keluarga dapat terjalin dengan harmonis. Kejujuran juga akan menciptakan komunikasi yang baik antara orang tua dan anak dan akan terciptanya rasa kepercayaan (Chairilsyah, 2016). Eric Erickson mengajukan tahap perkembangan psikologis dalam perkembangan individu, yaitu tahun pertama seorang anak harus mengembangkan suatu kepercayaan dasar (basic trust), tahun kedua dia harus mengembangkan otonominya, tahun selanjutnya dia harus mengembangkan kemampuan inisiatif dan industri yang menderong kearah penemuan identitas dirinya(Inten, 2017). Sadarjoen dalam Daviq mendefinisikan bahwa jujur diekspresikan dengan kata-kata atau sikap yang mencerminkan keadaan yang sesungguhnya, tidak ditutupi atau bahkan tidak menipu. Jujur adalah energi yang positif yang menyatakan sesuatu dengan langsung, spontan, lugas, apa adanya akan menghemat waktu dan energi, terjadilah efisiensi (Chairilsyah, 2016). Bagi anak kejujuran adalah menyampaikan berbagai hal apa adanya. Menyampaikan apa yang ia ketahui dengan penuh keberanian. Sikap jujur anak harus di pupuk dan didukung oleh orang tua dan pendidik agar dapat tumbuh subur dalam dirinya. Berawal dari kebiasaan anak untuk jujur pada dirinya, maka ia akan terbiasa berani untuk menyampaikan gagasan, ide-ide serta menyelesaikan masalah yang dihadapinya (Inten, 2017). Menurut hasil penelitian indikator yang dijadikan penilaian kejujuran anak yaitu (1) anak tidak menuduh orang lain atau mengatakan hal yang tidak benar terkait orang lain, (2) anak tidak menutupi kesalahan yang dilakukannya, (3) anak menjelaskan peristiwa sesuai fakta, (4) anak dapat mematuhi aturan, (5) anak tidak mengambil sesuatu yang bukan miliknya, (6) anak meminta izin saat menggunakan/mengambil barang yang bukan miliknya, (7) anak mengembalikan barang yang dipinjam, (8) anak mengetahui perbuatan yang tepat dan tidak tepat, (9) menyadari dan 
mengakui kesalahannya(Yasbiati et al., 2019). Kejujuran yang ditanamkan sejak dini oleh keluarga akan tumbuh subur dan terjaga dengan baik dalam setiap diri anak.

Pada tahap perkembangan moral menurut Piaget membagi tahap-tahap perkembangan moral berdasarkan cara penalarannya pada usia 4-7 tahun berada pada tahap moralitas heteronom; pada tahap ini cara berpikir anak tentang keadilan dan peraturan bersifat obyektif dan mutlak (dalam Monks, Knoer, \& Haditono, 2001), artinya tidak dapat diubah dan tidak dapat ditiadakan oleh kekuasaan manusia. Menurut Piaget (Santrock \& Santrock, 2007) sensorymotor ( 0 - 2 tahun) sampai fase perkembangan pra operasional termasuk kedalam perkembangan kognisi. Ciri khas yang paling nampak pada fase tersebut adalah anak senang meniru dan menyerap perilaku orang disekelilingnya (Santrock John W, 2009). Pada fase ini, anak sedang dalam masa pertumbuhan dan perkembangan yang sangat pesat baik secara emosional, intelektual, kepribadian, bahasa, dan moral. Rumus untuk mendorong seseorang berbuat baik (act morally) adalah melalui tiga dimensi dari karakter yaitu kompetensi (competence), keinginan (will), dan kebiasaan (habit) (Megawangi, 2004). Terintegrasinya ketiga aspek tersebut menjadikan siswa terbiasa untuk berperilaku baik, sehingga ia menjadi terbiasa pula melakukan perbuatan baik dan akan merasa bersalah kalau tidak melakukan perbuatan baik, Perlu adanya keteladanan dalam menanamkan ketiga aspek tersebut agar dapat ditiru oleh anak sejak usia dini.

Pendidikan pertama yang dialami setiap orang adalah pendidikan dalam keluarga, yakni melalui komunikasi antara orang tua dan anak, berupa bimbingan. Zakiah Derajat mengatakan bahwa orang tua adalah pembina pribadi yang pertama dalam hidup anak. Kepribadian orang tua, sikap dan cara hidup mereka, merupakan unsur-unsur pendidikan yang tidak langsung, yang dengan sendirinya akan masuk ke dalam pribadi anak yang sedang berkembang pada saat itu. Keluarga merupakan pendidikan yang pertama dan utama bagi anak. Pola asuh memiliki pengaruh dalam membentuk kejujuran karena kejujuran dapat dibentuk dari rumah (Yanizon, 2017). Proses pembentukan karakter adalah bagaimana anak-anak didik diberi pengetahuan dan pemahaman akan nilai-nilai kebaikan yang universal (moral knowing) sehingga pada akhirnya membentuk beliefs (Francisca \& Ajisuksmo, 2015). Pada saat anak sudah memiliki belief maka anak akan memiliki keyakinan untuk melakukan tindakan moral.

Keteladanan orang tua merupakan bagian terpenting dalam membentuk karakter anak, karakter keluarga. Keteladanan dan pembiasaan merupakan unsur yang sangat penting dalam proses melakukan sikap perilaku anak. Pendidik atau guru sudah seharusnya menjadi contoh 
utama sebelum menanamkan karakter pada anak (Pitaloka et al., 2021). Metode keteladanan merupakan influentif yang paling meyakinkan bagi keberhasilan pembentukan aspek moral, spiritual dan etos sosial peserta didik (Mustofa, 2019). Orangtua juga harus memiliki pemahaman dan pengetahuan yang memadai serta kepribadian yang baik agar bisa memberikan keteladanan kepada anak, terutama terkait dengan masalah kejujuran. Ada banyak langkah yang bisa dijalankan, dan yang paling penting adalah bagaimana menanamkan kesadaran yang utuh kepada anak agar menjadikan kejujuran sebagai sebuah hal yang positif bagi kehidupannya, sehingga anak mampu memiliki pemahaman akan perbedaan karakter baik dan buruk serta apa konsekuensinya dalam kehidupan. Fungsi orang tua dalam keluarga diantaranya (1) orang tua dapat memberikan penjelasan mengenai hal baik dan buruk bagi anak, penting bagi anak untuk mendapat penjelasan terhadap kelakuan itu boleh dilakukan. (2) pendidikan yang keras juga akan menyebabkan anaknya menjadi keras, menggunakan pola pendidikan yang keras akan menyebabkan anak-anak menjadi disiplin, namun malah juga akan meningkatkan kemungkinan seorang anak untuk tidak nyaman. (3) apa yang dilakukan orang tua akan ditiru oleh anak, anak akan mengikuti apa yang menjadikan kebiasaan orang tuanya. Jadi dalam mendidik anak untuk memiliki karakter yang baik, orang tua harus memberi contoh yang positif kepada anak baik dalam tingkah laku atau berbicara. (4) orang tua harus bisa menjaga anaknya dari lingkungan social yang buruk. Apabila orang tua sudah mendidik anaknya dengan baik, maka disamping itu orang tua harus bisa menjaga atau mengawas anaknya dalam kehidupan bersosial. (5) memberi kasih saying dan semangat, orang tua harus memberi kasih sayang dan menghargai anak, baik di saat mereka mendapatkan nilai ujian yang bagus maupun ketika mereka tidak mendapat hasil yang diinginkan karena sesungguhnya mereka telah bekerja keras.

Dalam Undang-undang No. 14 Tahun 2005 tentang Guru dan Dosen dikemukakan kompetensi pedagogik adalah "Kemampuan mengelola pembelajaran peserta didik". Depdiknas menyebut kompetensi ini dengan "kompetensi pengelolaan pembelajaran. Perencanaan pembelajaran merupakan proses pengambilan keputusan hasil berpikir secara rasional tentang sasaran dan tujuan pembelajaran tertentu dengan memanfaatkan segala potensi dan sumber daya yang ada. Inti dari perencanaan pembelajaran adalah kegiatan pemilihan, penetapan, dan pengembangan metode yang didasarkan pada kondisi pengajaran yang ada (B.Uno, 2008). Sikap yang diterapkan dimasukkan dalam Rencana Pelaksanaan Pembelajaran Harian (RPPH) atau dalam Standar Operating Procedure (SOP) harian dari pagi hingga anak 
pulang sekolah. Dalam menerapkan kejujuran di sekolah anak dapat mencontoh perilaku jujur melalui perilaku guru. Selain itu juga guru dapat menampilkan kisah atau dongeng atau film yang menceritakan tentang manfaat dan manisnya kejujuran, agar anak dapat memahami dan meniru bahwa perilaku jujur itu menyenangkan dan banyak manfaatnya, di antaranya disayang teman, guru, orang tua dan orang-orang di sekitar. Selain itu juga dengan berperilaku jujur, seseorang akan banyak teman, dipercaya dan dihormati serta dihargai.

Pemberian reward mampu mempengaruhi sosial emosional anak. Dimana reward digunakan oleh guru untuk memberikan penghargaan atas diri anak seutuhnya (Agustina et al., 2021) Penghargaan atau reward penting untung merangsang, menarik, mempertahankan, memberi motivasi, pembiasaan baik untuk meraih suatu pencapaian. Pujian tetap menjadi sarana efektif bukan hanya untuk anak-anak, tapi juga untuk orang dewasa. Pujian membawaperasaan tersendiri untuk melakukan hal yang dipujikan lebih baik lagi. Sedangkan hukuman Dengan demikian metode reward dan punishment ini baik diterapkan untuk mendukung perkembangan perilaku jujur. Sebagaimana yang diungkapkan oleh Pada dasarnya, yang termasuk ke dalamkelompok usia dini adalah kelompok usia 4-6 tahun yaitu usia sekolah Taman Kanak-Kanak Kelompok A dan Kelompok B. Karena itulah, menurut Lawrence Kohlberg, usia kemampuan penalaran moral anak usia 4-6 tahun adalah berada pada tahap penalaran moral pra-konvensional. Usia penalaran Pra Konvensional dibagi menjadi dua tahap, yaitu (Slavin, 2009): (1) tahap pertama adalah tahap orientasi hukum dan ketaatan (the punishment-obiedience level) (Slavin; Robert E, 2009).

\section{SIMPULAN DAN SARAN}

Hasil penelitian dapat disimpulkan bahwa Sekolah PAUD Barisanmu memiliki program pembelajaran untuk menanamkan kejujuran melalui: 1) memberikan program latihan; 2) bekerja sama dengan orang tua di rumah; 3) memberikan pengetahuan tentang nilai-nilai kejujuran; 4) mengunakan metode penanaman nilai dan keteladanan; 5) melakukan perencanaan pembelajaran; 6) memberikan reward (hadiah) dan punishment (hukuman). Adapun saran untuk penelitian berikutnya sebaiknya guru mengajak anak untuk praktik kejujuran di rumah dan di sekolah. Pada pembelajaran guru mengintegrasikan nilai-nilai kejujuran dalam kegiatan pelaksanaan pembelajaran. 


\section{UCAPAN TERIMA KASIH}

Penulis mengucapkan terimakasih kepada pihak yang mendukung terhadap selesainya penelitian ini diantaranya guru PAUD Barisanmu Kepada anggota peneliti yang telah mendukung diantaranya ide dan gagasan dalam penelitian.

\section{DAFTAR PUSTAKA}

Agustina, M., Azizah, E. N., \& Koesmadi, D. P. (2021). Pengaruh Pemberian Reward Animasi terhadap Motivasi Belajar Anak Usia Dini selama Pembelajaran Daring. Jurnal Obsesi : Jurnal Pendidikan Anak Usia Dini, 6(1), 353-361.

https://doi.org/10.31004/obsesi.v6i1.1331

Annisa Anita Dewi. (2017). Guru Mata Tombak Kehidupan. CV Jejak.

B.Uno, H. (2008). Orientasi baru dalam psikologi pembelajaran. Bumi Aksara.

Chairilsyah, D. (2016). Metode dan Teknik Mengajarkan Kejujuran pada Anak Sejak Usia Dini. Jurnal Educhild, 5(1), 8-14.

Dan, S. S. P. (2017). Peran Guru PAI Dalam Mencegah Paham Radikalisme Bagi Siswa Di MTs Irsyadul Anam Kiyudan Selomartani Kalasan Sleman Yogyakarta. In Uin Sunan kalijaga Yogyakarta (Vol. 7, Issue 1). https://doi.org/10.1016/j.jenvman.2018.01.013

Dharma Kesuma, dkk. (2012). Pendidikan Karakter. PT Remaja Rosdakarya.

Fandi Setiawan. (2013). Kemampuan Guru Melakukan Penilaian dalam Pembelajaran Melalui Internalisasi Nilai Kejujuran pada Pembelajaran Pendidikan Kewarganegaraan. Jupis, 5(2), 75.

Fitria, Y. (2019). Perilaku Menyontek: Persepsi Terhadap Iklim Sekolah Dengan Ketidakjujuran Akademi. JIPI, Vol. 07(No.01).

Francisca, L., \& Ajisuksmo, C. (2015). The Correlations Among Moral Knowing, Moral Feeling, and Moral Behavior on Four Basic Competencies of Teachers. Jurnal Kependidikan, 45(2), 211-221.

Haiatin Chasanatin. (2015). Pengembangan Kurikulum. STAIN Jurai Siwo Metro, 18. Imam Wahyu. (2012). Mengejar Profesionalisme Guru. Prestasi Pustaka. Inten, D. N. (2017). Penanaman Kejujuran Pada Anak Dalam Keluarga. FamilyEdu, 3(1). Kementrian Pendidikan Nasional. (2005). Disain Induk Pendidikan Karakter. Kemendiknas. Megawangi, R. et al. . (2004). Patut dan Menyenangkan: Penerapan Teori Developmentally Appropriate Prac-tices (DAP) Anak-anak Usia Dini 0 samp 8 Tahun. Indonesia Heritage Foundation.

Muhammad Amin. (2017). Peran Guru Dalam Menanamkan Nilai Kejujuran Pada Lembaga Pendidikan. TADBIR : Jurnal Studi Manajemen Pendidikan, 1(1).

Munir dan Sudarsono. (2016). Dasar Agama Islam. Rineka Cipta.

Mustofa, A. (2019). Metode Keteladanan Perspektif Pendidikan Islam. Cendikia : Jurnal Studi Keislaman, 5(1). https://doi.org/10.37348/cendekia.v5i1.71

Pitaloka, D. L., Dimyati, D., \& Purwanta, E. (2021). Peran Guru dalam Menanamkan Nilai Toleransi pada Anak Usia Dini di Indonesia. Jurnal Obsesi : Jurnal Pendidikan Anak Usia Dini, 5(2), 1696-1705. https://doi.org/10.31004/obsesi.v5i2.972

Rochmawati, N. (2018). Peran Guru dan Orang Tua Membentuk Karakter Jujur Pada Anak. Jurnal Al-Fikri: Jurnal Studi Dan Penelitian Pendidikan Islam, 1(2), 1-12.

Samsul Munir Amin. (2016). Ilmu Akhlak. Hamzah. 
Santrock John W. (2009). Educational Psychology. Salemba Humanika.

Slavin; Robert E. (2009). Psikologi Pendidikan: Teori dan Praktik. PT. Indeks.

Tarman, I., \& Tarman, B. (2011). Developing effective multicultural practices: A case study of exploring a teacher's understanding and practices. The Journal of International Social Research, 4(17), 1-21.

Waseza, F. C. (2017). Implementasi Nilai Karakter Jujur Di Sekolah Bunda Paud Kerinci. Nur El-Islam, 4(2), 142-165.

Yanizon, A. (2017). Peran Orangtua Terhadap Perkembangan Moral Anak Dalam Keluarga Moral Development of Children Through the Role of Parents in a Family. KOPASTA: Jurnal Program Studi Bimbingan Konseling, 3(2), 46-55. https://doi.org/10.33373/kop.v3i2.553

Yasbiati, Y., Mulyana, E. H., Rahman, T., \& Qonita, Q. (2019). Profil Kejujuran Anak Usia 5-6 Tahun di RA-At-Taufiq Kota Tasikmalaya. Jurnal Pendidikan Anak, 8(2), 99-106. https://doi.org/10.21831/jpa.v8i2.28591 